\title{
INVESTIGATION OF KAOLIN BASED ONE PART GEOPOLYMERS
}

\author{
Sezer ÇETIN1*, Mehmet Uğur TOPRAK ${ }^{2}$, Seher GÜZ3 \\ ${ }^{1}$ Dumlupinar University, Hisarcık Vocational School, Land Registry and Cadastrate Pr., Kütahya \\ ORCID No : http://orcid.org/0000-0002-8976-3594 \\ 2Dumlupınar University, Faculty of Engineering, Department of Civil Engineering, Kütahya \\ ORCID No :http://orcid.org/0000-0001-5483-2871 \\ ${ }^{3}$ Dumlupınar University, Faculty of Engineering, Department of Metallurgy and Materials Engineering, Kütahya \\ ORCID No :http://orcid.org/0000-0003-4926-8035

\begin{tabular}{ll}
\hline Keywords & Abstract \\
\hline Kaolin, & Kaolin based one-part geopolymers (produced by adding water to preground \\
Geopolymer, & aluminosilicate+alkali mixture) were produced in this study. The effect of silica fume \\
Aluminosilicate, & addition and pre-curing time on microstructure, mechanical and mineralogical \\
Silica fume, & properties of geopolymers evaluated with X-ray Fluorescence (XRF), X-ray \\
Sodium hydroxide. & diffractometer (XRD), Scanning Electron Microscopy (SEM), Fourier Transform Infrared \\
& Spectrometer (FT-IR).7-day compressive strength of 66.73 MPa was obtained from \\
& kaolin-based one-part geopolymers. With the addition of silica fume, the strength \\
enhanced up to 88.57MPa.
\end{tabular}

\section{KAOLİN ESASLI TEK BİLEŞENLİ JEOPOLIMERLERİN İNCELENMESİ}

\begin{tabular}{|c|c|}
\hline Anahtar Kelimeler & Öz \\
\hline $\begin{array}{l}\text { Kaolin, } \\
\text { Jeopolimer, } \\
\text { Alüminosilikat, } \\
\text { Silis dumanı, } \\
\text { Sodyum hidroksit. }\end{array}$ & 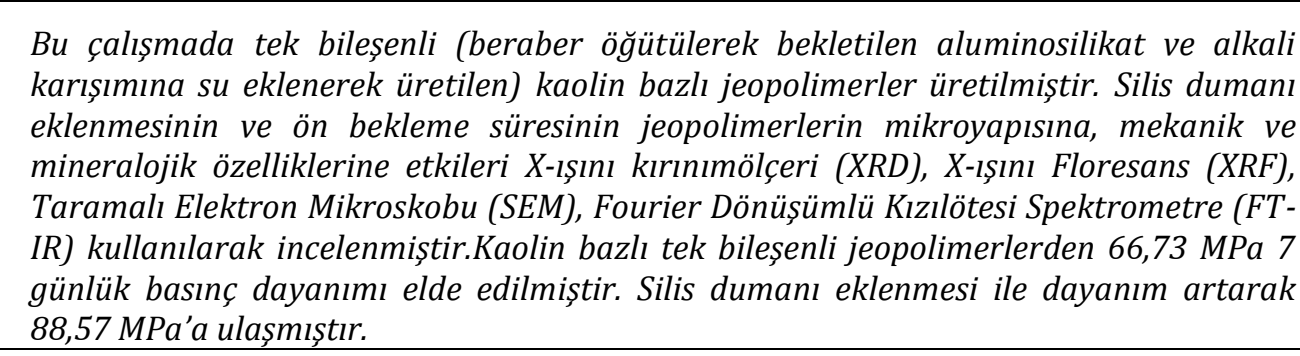 \\
\hline Araștırma Makalesi & Research Article \\
\hline Başvuru Tarihi & Submission Date \\
\hline Kabul Tarihi & Accepted Date \\
\hline
\end{tabular}

* Sorumlu yazar; e-posta : $\underline{\text { szrcetin@gmail.com }}$

$\mathrm{Bu}$ eser, Creative Commons Attribution License (http://creativecommons.org/licenses/by/4.0/) hükümlerine göre açık erişimli bir makaledir.

This is an open access article under the terms of the Creative Commons Attribution License (http://creativecommons.org/licenses/by/4.0/). 


\section{Introduction}

Victor Glukhovsky, in the 1960s and 1970s made major contribution in identifying both calcium silicate hydrates, and calcium and sodium alumino-silicate hydrates as solidification products in geopolymerization (Davidovits, 2020).

Davidovits began to work on new heat-resistant "plastic materials" after the catastrophic fires in France in 1970/73. Davidovits stated that these requirements can only be provided by inorganic polymermaterials and reported that a mineral such as kaolin may form a binder by alkali activation at a temperature as low as $100-150{ }^{\circ} \mathrm{C}$, instead of heat treatment at 1000 $1300^{\circ} \mathrm{C}$.He introduced the term of geopolymer in 1978 (Davidovits, 1988). Davidovits has defined $\mathrm{Si}-\mathrm{O}-\mathrm{Al}$ bond as sialate bond and $\mathrm{Si}-\mathrm{O}-\mathrm{Si}$ bond as siloxo bond for aluminosilicate structures and this aluminosilicate structures known as "inorganic polymers", "mineral polymers"(Davidovits, 1982). If Si/Al molar ratiosare 1, 2 and 3, this structures respectively defined as poly (sialate), poly(sialate-siloxo) and poly (sialate-disiloxo) (Davidovits, 1976).

The geopolymer is an amorphous semi-crystalline structure with a three-dimensional $\mathrm{Si}-\mathrm{O}-\mathrm{Al}$ polymeric network. Molecular sequences of geopolymer systems with different $\mathrm{Si} / \mathrm{Al}$ ratios and share of all oxygen atoms of $\mathrm{SiO}_{4}$ and $\mathrm{AlO}_{4}$ tetrahedrals shown in Figure 1 (Palomo, Grutzeck and Blanco-Varela, 1999; Provis, Lukey and van Deventer, 2005).

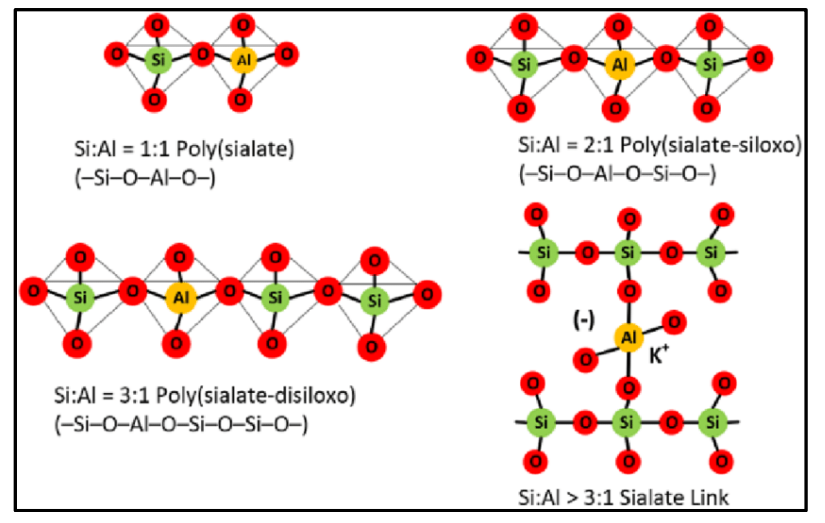

Figure 1. Molecular Sequences of Geopolymer Systems (Al Bakri Abdullah, Liew, Heah and Mohd Tahir, 2018)

In quadruplex coordinated $\mathrm{Al}$, negative chargesare balanced with cations such as $\mathrm{Na}^{+}, \mathrm{K}^{+}, \mathrm{Li}^{+}, \mathrm{Ca}^{+2}, \mathrm{Ba}^{+2}$ and $\mathrm{H}_{3} \mathrm{O}^{+}$(Allahverdi, Mehrpour and Kani, 2008)

Geopolymerization is an exothermic reaction and forms three-dimensional macro molecular structures through oligomers. The structure proposed by Davidovits is given in Figure 2(Davidovits, 1991) (Davidovits, 1994).

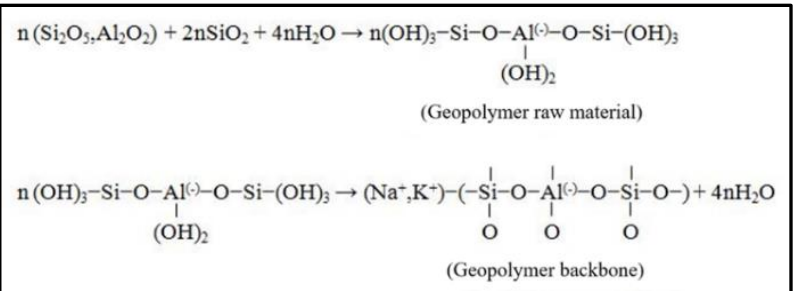

Figure 2. Schematic Representation of Geopolymerization Process

The presence of hydroxyl ions in the alkaline medium initiates the dissolution process of the aluminosilicates and liberates the silicate and aluminate species to promote further-polymerization reaction (Komnitsas and Zaharaki, 2007) (Davidovits, 1988). The degree of dissolution depends on fineness, ion-exchange ability, concentration of alkali solutions and the structure of the precursors. It has been suggested that the geopolymerization reactions occur simultaneously and in multiple steps (van Jaarsveld, van Deventer and Lukey, 2002), (Alonso and Palomo, 2001), (Dimas, Giannopoulou and Panias , 2009).

Geopolymers are divided into two according to the production method. First is conventional (two-part) geopolymers that formed by a reaction between a concentrated aqueous solution of alkali hydroxide, sulfate, silicate, or carbonate.(Provis and van Deventer, 2009) (Duxson, et al., 2007) (Provis, 2014)(Provis, et al., 2014) (Provis, 2009).

Second one is one-part geopolymers that demonstrate significant point on geopolymer technology having been described by the first time in 2007 (Koloušek, Urbanova, Andertova, Hulinsky and Vorel, 2007) (Shi, Fernández-Jiménez and Palomo, 2011). In one-part geopolymers, solid activators such as calcium hydroxide, sodium hydroxide, calcium carbonate, or sodium metasilicate are blended with geopolymer precursors like rice husk ash, silica fume, or fly ash, then just water is added to initiate the geopolymerization. The dissolution process of the solid phase starts rapidly after adding water to the dry mixture (Abdollahnejad, Pacheco-Torgal and de Aguiar, 2015) (Ma, Long, Shi, \& Xie, 2018).

Researchers have studied on one-part geopolymer system because of its economic value, whereby geopolymer compound can be prepared by just adding waterto aluminosilicate-alkali mixes (Sturm, Greiser, Gluth, Jäger and Brouwers, 2015) (Ke, Bernal, Ye, Provis and Yang, 2014) (Peng, Wang, Shen and Xiao, 2015). With this approach, it is not necessary to use highly alkaline compound or sodium hydroxide solutions which prevent problems with carbonation and ageing of these solutions as well as safety issues. (Hajimohammadi, Provis and van Deventer, 2008 ). But 
recent investigations (Peng, Wang, Shen and Xiao, 2015)support that one-part geopolymers show low mechanical strength.

Usually, the method for producing metakaolin consists in heating kaolin between 700 and $850{ }^{\circ} \mathrm{C}$, giving an amorphous material. Then it contains exclusively 50$55 \%$ of $\mathrm{SiO}_{2}$ and $40-45 \%$ of $\mathrm{Al}_{2} \mathrm{O}_{3}$ by weight and is very reactive with respect to an alkaline and calcium-rich solution (Konan, et al., 2009) (Poon, Lam, Kou, Wong, and Wong, 2001)(Shvarzman, Kovler, Grader, and Shter, 2003).

The aims of the present study arei) to evaluate usability of kaolin as raw material in geopolymersii) to determine the effect of silica fume (SF) on properties of geopolymers. For this purpose, mechanical, mineralogical, and microstructural analyses wereconducted on geopolymer samples.

\section{Materials and Methods}

In this study, research and publication ethics principles were followed.

\subsection{Materials}

The Blaine fineness of kaolin $(\mathrm{K})$ used in this studywas $5000 \mathrm{~cm}^{2} / \mathrm{g}$. XRD patterns reveals that $\mathrm{SF}$ was completely amorphous anditsspecific surface area (measured with the BET method) typically ranges from 150000 to $300000 \mathrm{~cm}^{2} / \mathrm{g}$. (Yeğinoball, 2009)(Tonak, Sipahi and Atay, 1997) (Aldred, et al., 2000).

Ye et al. (2016) stated that the addition of silica fumes up to $20-25 \%$ clearly has a positive effect on the compressive strength of the one-part geopolymers.This is because silica fume, which has small particle sizes and consists of a high amount of amorphous silicon dioxide, is a highly reactive pozzolanic material(Jithendra and Elavenil, 2020).

In this study, 8.48 wt\% of SF with respect to the mass of total solid were used to produce different geopolymer precursors.Sodium hydroxide pellets $(98 \%$ purity) was obtained from a local market in Eskişehir/TURKEY.

Chemical composition ofKand SF obtained by using an X-ray Fluorescence Spectrometer (Panalytical Axios Spectrometer)at Dumlupinar University ILTEM department were given in Table 1.

Table 1.

Chemical Composition of Kaolin and Silica Fume

\begin{tabular}{ccccccccccccc}
\hline Composition & $\mathrm{SiO}_{2}$ & $\mathrm{Al}_{2} \mathbf{O}_{3}$ & $\mathrm{Fe}_{2} \mathbf{O}_{3}$ & $\mathbf{M g O}$ & $\mathbf{C a O}$ & $\mathrm{K}_{2} \mathbf{O}$ & $\mathrm{Na}_{2} \mathbf{O}$ & $\mathbf{P}_{2} \mathbf{O}_{5}$ & $\mathrm{TiO}_{2}$ & $\mathbf{S O}_{3}$ & $\mathrm{MnO}$ & $\mathbf{L O I}$ \\
\hline w \% of K & 47.05 & 37.07 & 0.83 & 0.31 & 0.08 & 1.90 & 0.07 & 0.12 & 0.06 & 0.04 & - & 13 \\
\hline w \% of SF & 92.41 & 0.74 & 0.86 & 1.15 & 0.43 & 1.09 & 0.41 & 0.23 & - & 0.21 & 0.07 & 2.36 \\
\hline
\end{tabular}

LOI: Loss on Ignition

\subsection{Methods}

Geopolymer samples were produced by one-part production method described below. Composition and production details of geopolymer series were given in Table 2.

One-part geopolymer(OPG): aluminosilicates (K or $\mathrm{K}+\mathrm{SF}$ ) and the alkali ( $\mathrm{NaOH}$ pellets) were ground together with ring mill(Figure 3) for 30 minutes. After pre-cure in plastic bags for 1 or 2 day in ambient conditions, ready mix was only mixed with distilled water and pressed in $25 \mathrm{~mm}$ cylindrical mold (Figure 4.a) under 12 tons with hydraulic press (Figure 4.b).

Studies have indicated that pre-cured samples show some minor cracks compared to open cured samples without pre-curing. During pre-curing, the binder gains some strength. At a low temperature such as room temperature, the water evaporation and hence the capillary forces are not too high. Therefore, crack formation is prevented. After pre-curing, the binder acquires enough strength to withstand capillary forces and gains its ultimate strength without too many cracks(Peys, Rahier and Pontikes, 2016).For this reason, the effect of the increase in pre-curing time on compressive strength was investigated.

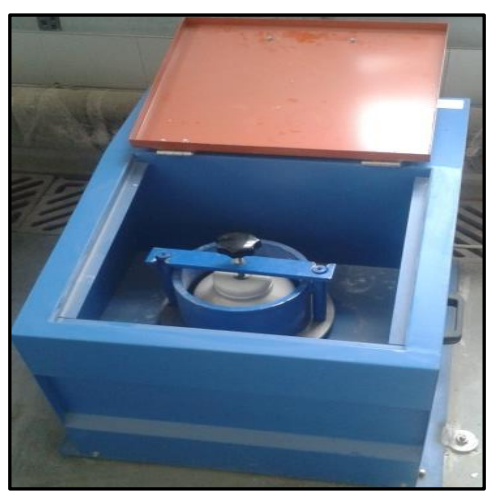

Figure 3. Ring Mill 
Steam Cure (SC) was applied to one-part geopolymer samples in the digital water bath shown in Figure 5 (a) and the samples $(25 \times 50 \mathrm{~mm}$ cylinder) obtained were given in Figure 5 (b).

Table 2.

Composition and Production Data of Geopolymer Series

\begin{tabular}{ccccccccc}
\hline Sample Code & $\mathrm{K}, \mathrm{g}$ & $\begin{array}{c}\mathrm{SF}, \\
\mathrm{g}\end{array}$ & $\begin{array}{c}\mathrm{NaOH}, \\
\mathrm{g}\end{array}$ & $\begin{array}{c}\mathrm{W}, \\
\mathrm{ml}\end{array}$ & $\begin{array}{c}\text { Pre-curing, } \\
\mathrm{d}\end{array}$ & $\begin{array}{c}\text { Curing } \\
\text { Type }\end{array}$ & $\begin{array}{c}\text { Curing } \\
\text { Temp. } \\
\left({ }^{\circ} \mathrm{C}\right)\end{array}$ & $\begin{array}{c}\text { Curing } \\
\text { Time. } \\
(\mathrm{h})\end{array}$ \\
\hline $\mathrm{K}-1$ & 88.90 & - & 11.10 & 5 & 1 & $\mathrm{SC}$ & 60 & 5 \\
$\mathrm{~K}+\mathrm{SF}-1$ & 80.42 & 8.48 & 11.10 & 5 & 1 & $\mathrm{SC}$ & 60 & 5 \\
$\mathrm{~K}-2$ & 88.90 & - & 11.10 & 5 & 2 & $\mathrm{SC}$ & 60 & 5 \\
$\mathrm{~K}+\mathrm{SF}-2$ & 80.42 & 8.48 & 11.10 & 5 & 2 & $\mathrm{SC}$ & 60 & 5 \\
\hline
\end{tabular}

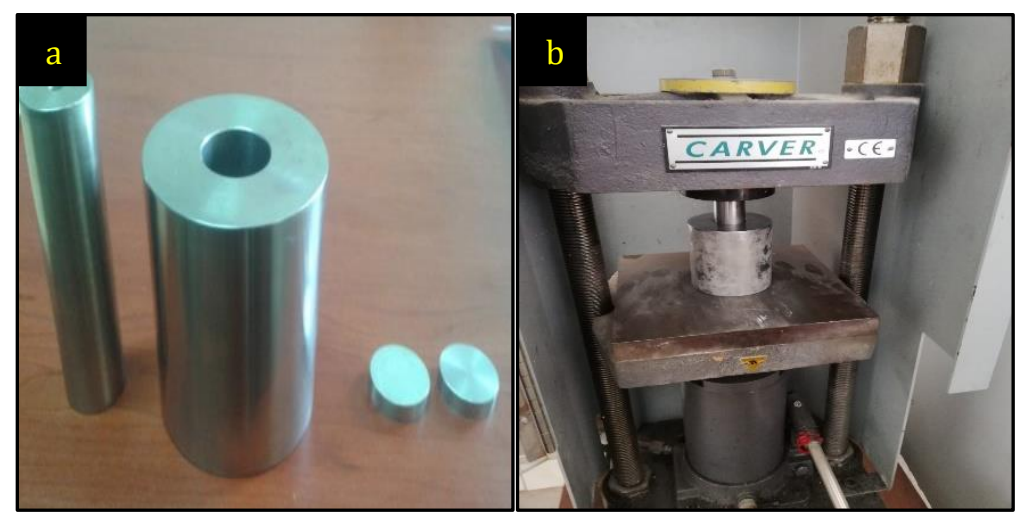

Figure 4. (a) 25 mm Cylindrical Mold (b)Hydraulic Press

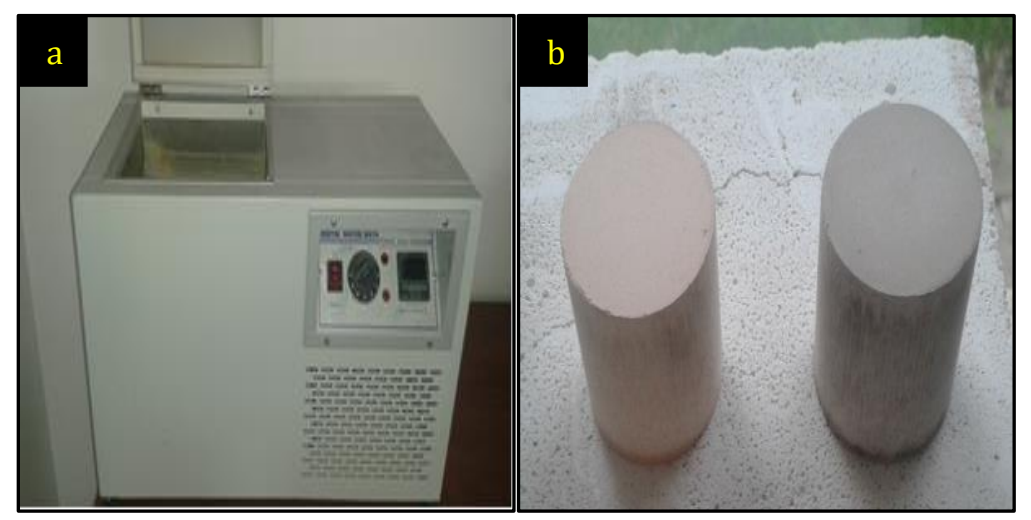

Figure 5. (a) Digital Water Bath Used for Steam Cure(b)One-Part Geopolymer Samples

\subsection{Characterization}

After steam curing, geopolymers were stored at an ambient temperature up to testing time. The loading speed of the uniaxial compression test device used in the test should be selected as a constant loading speed between $0.2 \mathrm{MPa} / \mathrm{sec}-1.0 \mathrm{MPa} / \mathrm{sec}$ with respect to TS EN 12390-3. Therefore, compressive strengths of the geopolymer series were measured at $7 \mathrm{~d}$. with uniaxial compression test device under loading speed of 0.6 
$\mathrm{MPa} / \mathrm{sec}$. All the reported results are the means of three samples. Phase analysis of raw kaolin and onepart geopolymer samples (K-2 andK+SF-2) were obtained by using Panalytical Empyrean XRD device at Dumlupinar University ILTEM department with a scanning speed of $1^{\circ}$ in a minute between 5-70 ${ }^{\circ}$. FTIR spectroscopy was performed between 400-4000 $\mathrm{cm}^{-1}$ wave number using Bruker Alpha brand FT-IR device for K-2 andK+SF-2. Zeiss Supra 50VP scanning electron microscope (SEM) was used for SEM microstructure analysis of $\mathrm{K}+\mathrm{SF}-2$ (the highest compressive strength).

\section{Results}

\subsection{Compressive Strength Analysis}

SF addition has positivelyaffected the compressive strengthof geopolymers as expected(Figure 6).Extending the pre-cure time up to 2 days almost doubled the compressive strength of the 1-dayprecured geopolymer samples.

A study conducted in the literature, the 3-day compressive strength of calcined kaolin with amorphous structure and high reactivity found $63 \mathrm{MPa}$ at most. In this study, calcined kaolin and $\mathrm{NaOH}$ or $\mathrm{Na}_{2} \mathrm{CO}_{3}$ were used (Peng et al., 2015). However, in our study, 7-day compressive strength was obtained with a maximum of $66.73 \mathrm{MPa}$ with a mixture of uncalcined kaolin and $\mathrm{NaOH}$, and this value was increased up to 88.57 MPa with silica fume additive.

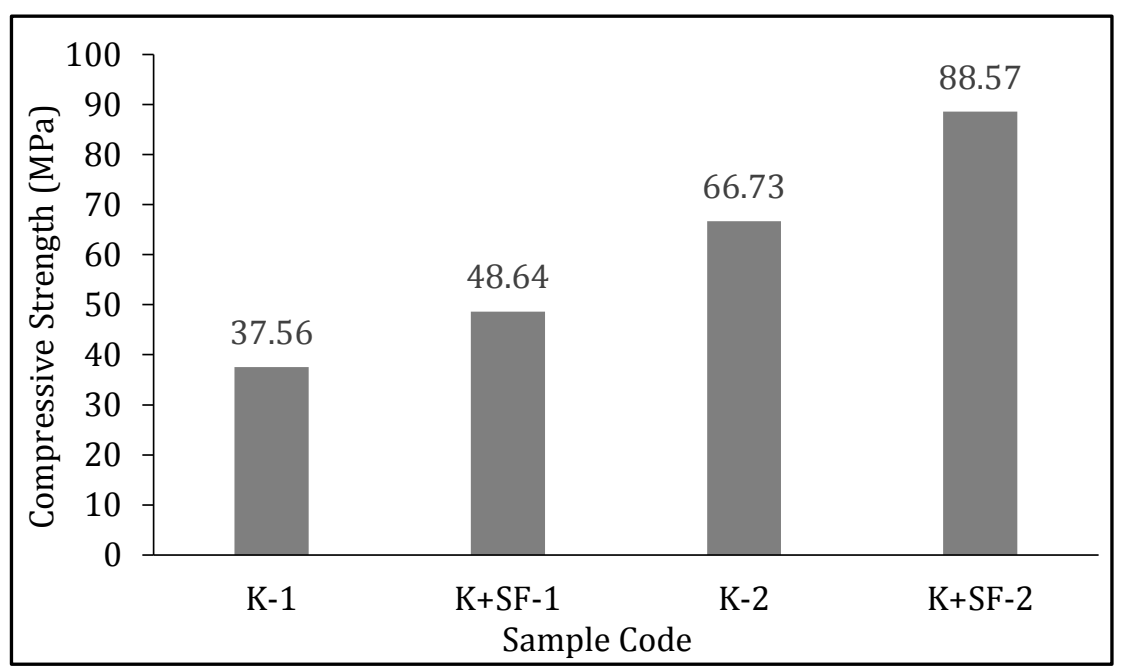

Figure 6. 7-Day Compressive Strength of Geopolymer Samples

\subsection{XRD Phase Analysis}

Kaolinite, anorthite, stishovite and illite were obtained in kaolin. Kaolinite peaks are observed at $2 \theta$ (degrees); $12.3^{\circ}-24.9^{\circ}-45.4^{\circ}-55.1^{\circ}-62.2^{\circ}$. The intensities of kaolinite and illite decreased in the XRD pattern of K-2 and $\mathrm{K}+\mathrm{SF}-2$ samples in consequence of geopolymerization. Geopolymers show generally amorphous X-ray diffraction (XRD) pattern without sharp peaks at $2 \theta$ between 25 and $30^{\circ}$ (Lecomte, Liégeois, Rulmont, Cloots and Maseri, 2003).

As the $\mathrm{Si} / \mathrm{Al}$ ratio in $\mathrm{K}+\mathrm{SF}-2$ increased, intensity of peaks at the $2 \theta$ range from $20^{\circ}$ to $25^{\circ}$ decreased as well as the amorphous pattern considerably disappeared.Increasing $\mathrm{Si} / \mathrm{Al}$ ratio increases the angles of sharp peaks(Lizcano, Kim, Basu and Radovic, 2012).

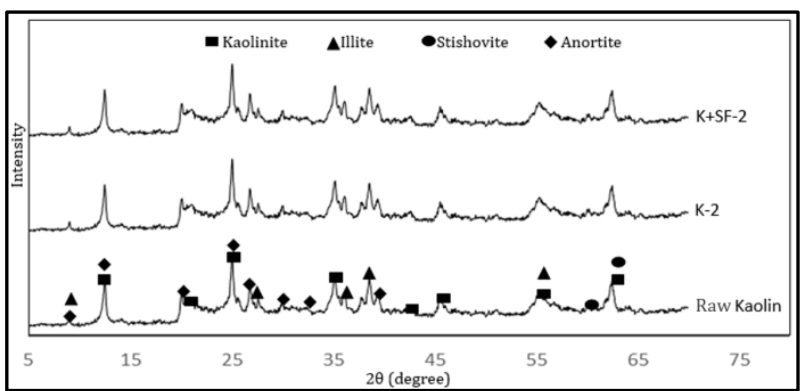

Figure 7. XRD Patterns Obtained from Test Samples

\subsection{FT-IR Analysis}

FT-IR analysis was performed to support geopolymer formation. In the FT-IR spectra of geopolymers, Milkey observed the relationship between the frequency of the 
absorption bands and the $\mathrm{Si}: \mathrm{Al}$ ratio in the aluminosilicate frame. According to this, as the amount of $\mathrm{Al}$ increases, the wavenumber decreases(Milkey, 1960). In the FT-IR analysis shown in Figure8, the bands in the $3600-3800 \mathrm{~cm}^{-1}$ wave number region are caused by hydration of water connected to the structure.

Peaks around $690 \mathrm{~cm}^{-1}$ wave number indicate Si-0 symmetrical vibration band. Peaks around $565 \mathrm{~cm}^{-1}$ wave number indicate $\mathrm{Si}-\mathrm{O}-\mathrm{Si}$ or $\mathrm{Si}-\mathrm{O}-\mathrm{Al}$ symmetrical strain. $\mathrm{Si}-\mathrm{O}-\mathrm{Si}$ or $\mathrm{Si}-\mathrm{O}-\mathrm{Al}$ network structure is observed at peaks around $460 \mathrm{~cm}^{-1}$. Inorganic polymers consist of $\mathrm{Si}-0$ tetrahedra. These tetrahedras are connected to each other by oxygen bridges at their corners. Considering the FT-IR analysis, peaks around 1030 and $1000 \mathrm{~cm}^{-1}$ wave number is taken to $900 \mathrm{~cm}^{-1}$ wave number with heat treatment and geopolymerization. This withdrawal is indicative of structural changes. FT-IR spectra of geopolymers showed similar wavenumber with different intensities regardless of silica fume addition. The main peak analyzed in the FT-IR spectrum of geopolymers was in the region of $900-1250 \mathrm{~cm}^{-1}$ corresponding to the Si$\mathrm{O}-\mathrm{Al}$ or $\mathrm{Si}-\mathrm{O}-\mathrm{Si}$ linkages. $\mathrm{K}+\mathrm{SF}-2$ 's main peak was lower thanK-2's main peak.

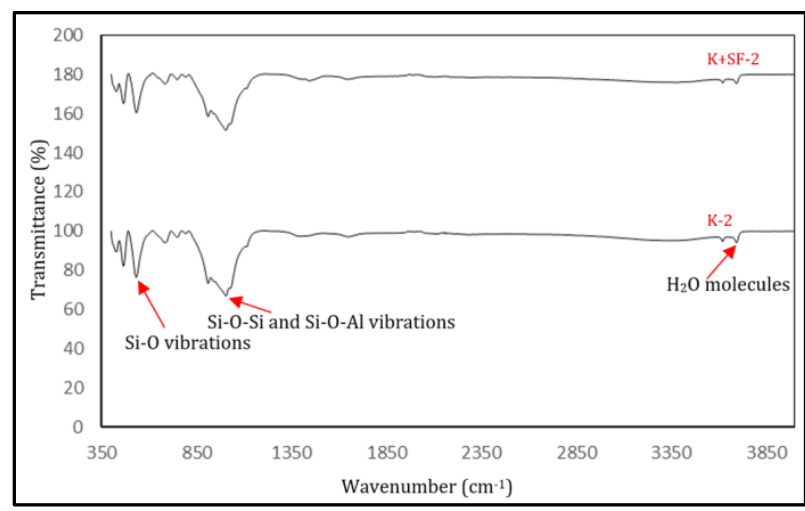

Figure 8. FT-IR Analysis Obtained from Test Samples

\subsection{SEM Microstructures and EDX Spectrum Analysis}

Figure 9-10 showed the microstructure of the geopolymers at different magnifications. EDX (Energy dispersive X-ray) analysis of the study were given in Figure 11-15. The rod structures seen in Figure 9-10 are insoluble sodium hydroxide crystals. The weight ratio (\%) of sodium in the structure at the selected areawas $29.86 \%$ which is the average of the spectrum $1-5$.The reason of the high sodium ratio was insoluble sodium hydroxide crystals given in Figure 9-10.
Sodium ratio in geopolymer structure in the spectrum 2 region shown in Figure 12was only $6.53 \%$.

SEM analysis shows that the geopolymer region is much denser than the insoluble alkali region. Joints at the grain boundaries and dense structure are manifested by the increase in compressive strength values in mechanical test results. It was determined by EDX analysis that sodium aluminosilicate structures were formed as a result of geopolymerization and the best results were observed in the samples produced by SF addition.

The EDX analysis of one-part geopolymer sample showed major element of $\mathrm{Si}, \mathrm{Al}$ and $\mathrm{Na}$. The physical and mechanical properties of geopolymer were a function of $\mathrm{SiO}_{2} / \mathrm{Al}_{2} \mathrm{O}_{3}$ and $\mathrm{Na}_{2} \mathrm{O} / \mathrm{Al}_{2} \mathrm{O}_{3}$ ratios(Sathonsaowaphak, Chindaprasirt and Pimraksa, 2009).

The geopolymer sample with the respectively $\mathrm{SiO}_{2} / \mathrm{Al}_{2} \mathrm{O}_{3}$ ratios of $1.53,1.96$ and the $\mathrm{Na}_{2} \mathrm{O} / \mathrm{Al}_{2} \mathrm{O}_{3}$ ratios of $0.37,1.37$ (as showed in Fig. 12 and 14) verified with reported of SEM images which the presence of strong geopolymer.

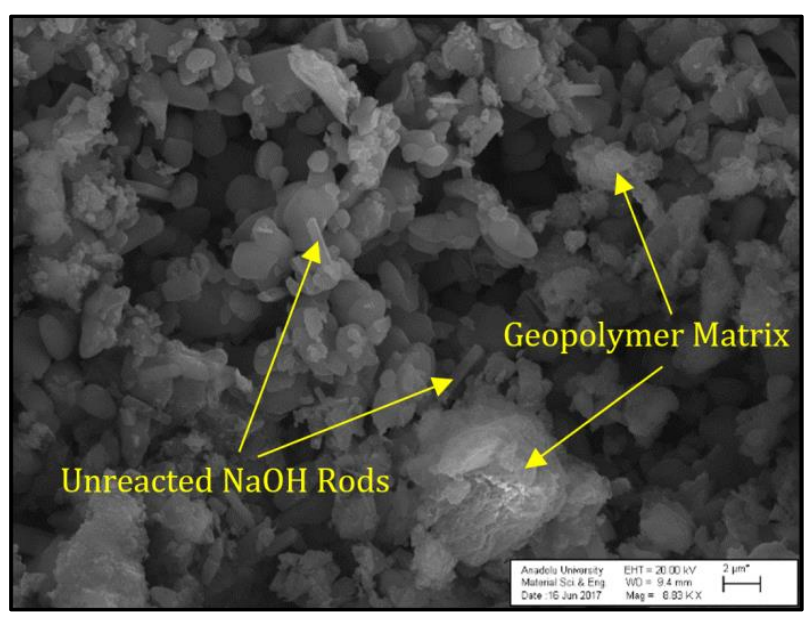

Figure 9. SEM Images Of K+SF-2 Sample 


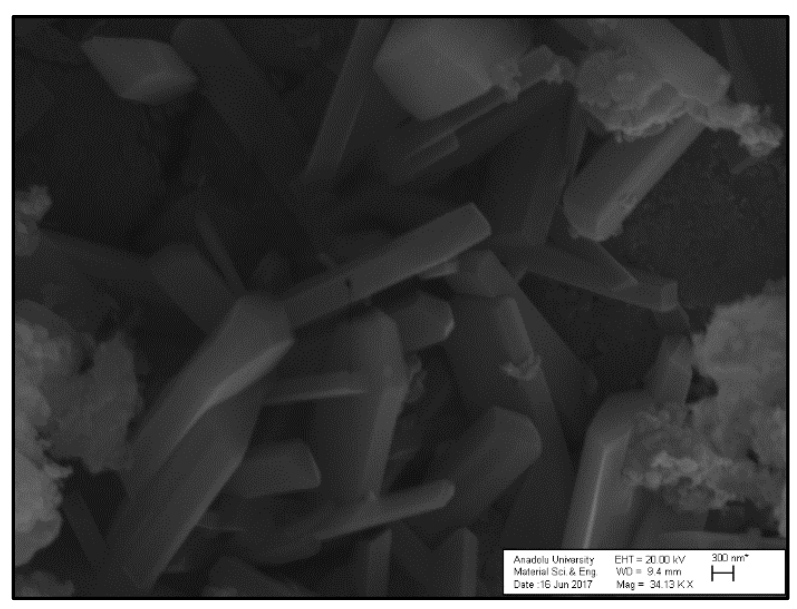

Figure 10. SEMImages Of K+SF-2 Sample at Different Magnifications

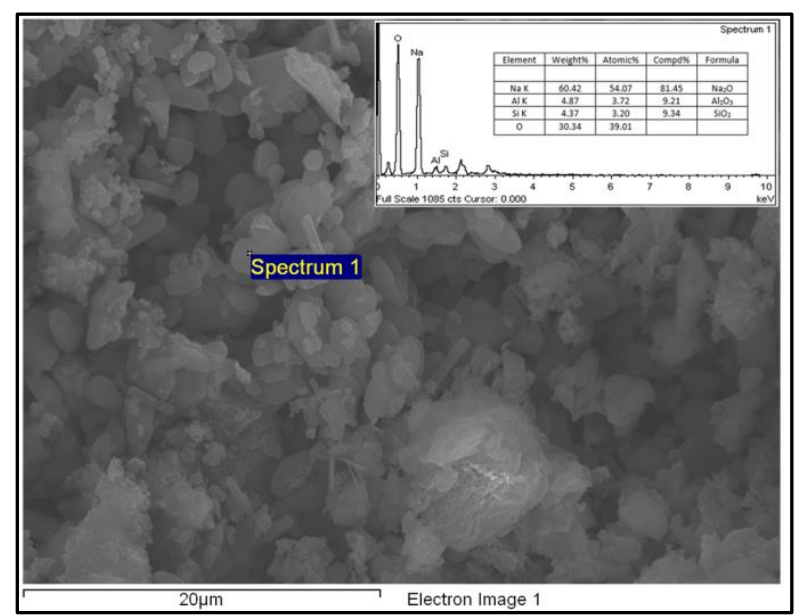

Figure 11. Microstructure Image and EDX Analysis K+SF-2 Sample

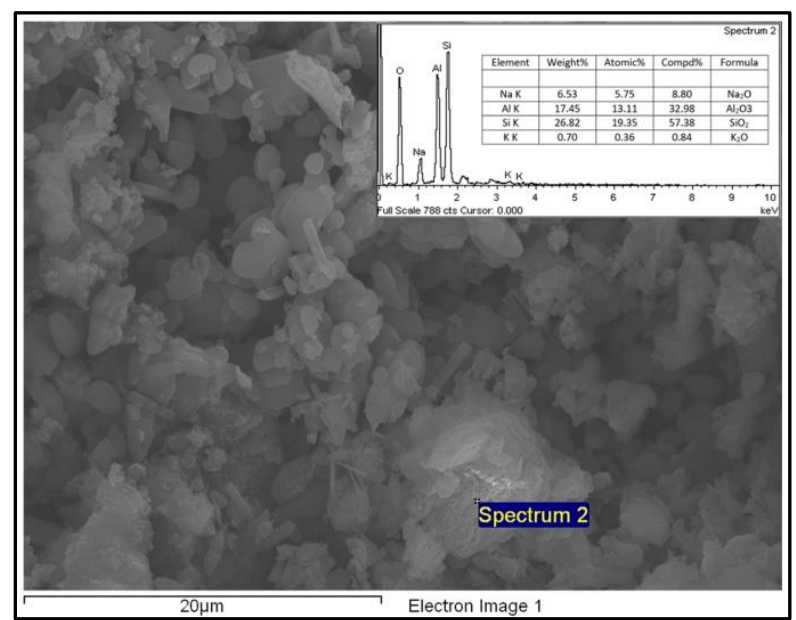

Figure 12. Microstructure Image and EDX Analysis from Different Point Of K+SF-2 Sample

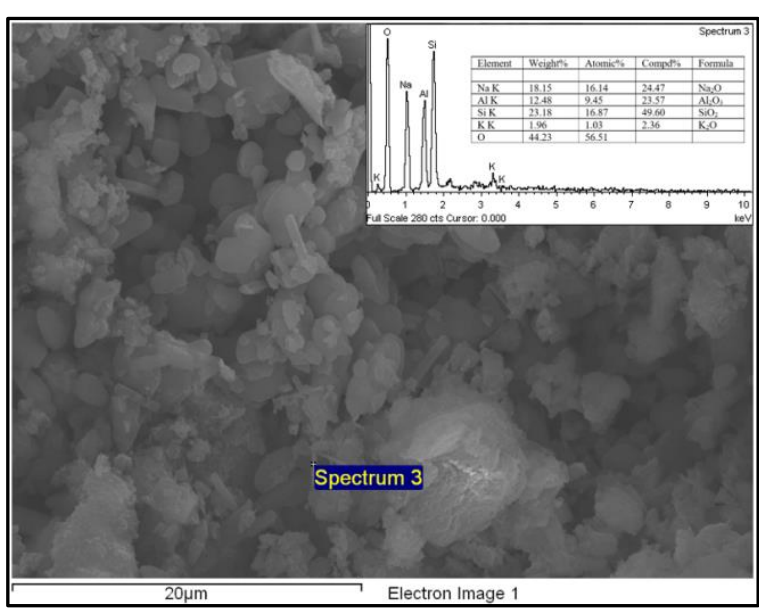

Figure 13. Microstructure Image and EDX Analysis from Different Point Of K+SF-2 Sample

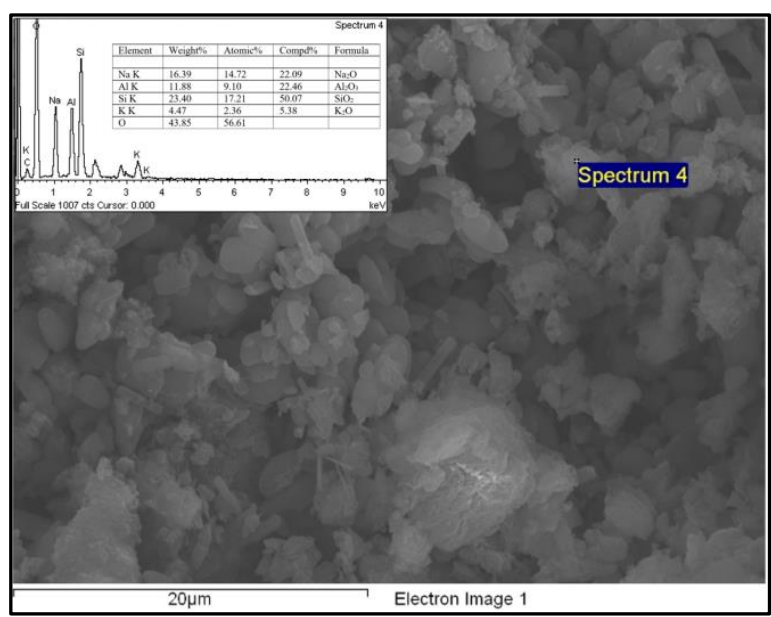

Figure 14. Microstructure Image and EDX Analysis from Different Point Of K+SF-2 Sample

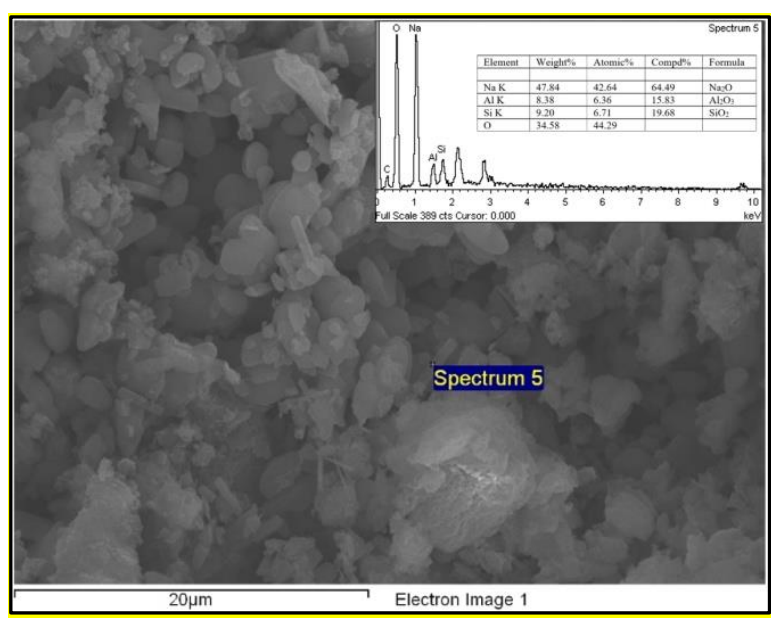

Figure 15. Microstructure Image and EDX Analysis from Different Point Of K+SF-2 S 


\section{Conclusion}

Results of this experimental study can be summarized as follows:

- $\quad$ The interatomic bonds examined in the FT-IR analysis revealsgeopolymer formation.

- The SEM observations supports the presence of geopolymer bonding at the grain boundaries.

- High strength one-part geopolymers were obtained using kaolin as aluminosilicate source.

- Kaolin can be preferred for geopolymer production considering economic and ecological reasons instead of metakaolin generally used for geopolymer production.

- $\quad 37.56 \mathrm{MPa}$ compressive strength was obtained in the sample $\mathrm{K}-1$ containing kaolin $+\mathrm{NaOH}+$ water, which was pre-curing for 1 day, but 66.73 MPa compressive strength was obtained in the sample $\mathrm{K}-2$ containing kaolin $+\mathrm{NaOH}+$ water for 2 days.

- $\quad$ 48.64 MPa compressive strength was obtained in the sample $\mathrm{K}+\mathrm{SF}-1$ containing kaolin + Silica Fume $+\mathrm{NaOH}+$ water, which was pre-curing for 1 day, but $88.57 \mathrm{MPa}$ compressive strength was obtained in the sample $\mathrm{K}+\mathrm{SF}-2$ containing kaolin + Silica Fume $+\mathrm{NaOH}+$ water for 2 days.

- In a kaolin based one-part geopolymer a decrease in the reaction rate was observed as the ratio of $\mathrm{SiO}_{2} / \mathrm{Al}_{2} \mathrm{O}_{3}$ increased. In addition, the increase in the ratio of $\mathrm{SiO}_{2} / \mathrm{Al}_{2} \mathrm{O}_{3}$ due to the addition of silica fume caused the formation of silica-rich phases and increased the amount of unreacted silica.

- Silica fume addition enhanced geopolymerization and the compressive strength of geopolymers.

The study was produced from the first author's thesis. Therefore, the article does not require legal / special permission (Çetin, 2017).

\section{Author Contributions}

In this article; Sezer ÇETIN, contributed to the concept, designed the research, experimental design, experimental work, analysis of results, discussed the results and reviewed the manuscript. Mehmet Uğur TOPRAK, contributed to the concept, designed the research, analysis of results, discussed the results and reviewed the manuscript. Seher GÜZ, contributed to experimental work, analysis of results, discussed the results and reviewed the manuscript.

\section{Conflict of Interest}

There is no conflict of interest.

\section{References}

Abdollahnejad, Z., Pacheco-Torgal, F., \& de Aguiar, J. B. (2015). Development of foam one-part geopolymers with enhanced thermal insulation performance and low carbon dioxide emissions. In Advanced Materials Research, 1129, 565-572. Trans Tech Publications Ltd. doi : https://doi.org/10.4028/ www.scientific.net/AMR.1129.565

Al Bakri Abdullah, M. M., Liew, Y. M., Heah, C. Y., \& Mohd Tahir, M. F. (2018). Clay-based materials in geopolymer technology. Cement Based Materials. London, UK:IntechOpen. doi: http://dx.doi.org/ 10.5772/intechopen.74438

Aldred, J. M., Bury, M. A., Detwiler, R. J., Fouad, F. H., Halczak, W., Holland, T. C., . . Z Zhang, M.-H. (2000). Guide for the use of silica fume in concrete. Report by ACI Committee.

Allahverdi, A., Mehrpour, K., \& Kani, E. N. (2008). Investigating the possibility of utilizing pumice-type natural pozzolan in production of geopolymer cement. Ceramics Silikaty, 52(1), 16-23.Retrieved fromhttps://www.ceramics-silikaty.cz/2008/pdf/ 2008_01_16

Alonso, S., \& Palomo, A. (2001). Calorimetric study of alkaline activation of calcium hydroxide-metakaolin solid mixtures. Cement and Concrete Research, 31(1), 25-30. doi: https://doi.org/10.1016/S0008$\underline{8846(00) 00435-X}$

Çetin, S. (2017). Alüminasilikat bazlı jeopolimerlerin incelenmesi (Master's thesis). Kütahya Dumlupınar University, Institute of Science, Department of Civil Engineering, Kütahya, Turkey.

Davidovits, J. (1976). Solid-phase synthesis of a mineral blockpolymer by low temperature polycondensation of alumino-silicate polymers: Napoly(sialate) or Na-PS and characteristics. IUPAC Symposium on Long-Term Properties of Polymers and Polymeric Materials. Stockholm, Sweden.

Davidovits, J. (1982). The need to create a new technical language for the transfer of basic scientific information. Transfer and Exploitation of Scientific and Technical Information, 316 - 320. Luxemburg. 
Davidovits, J. (1988). Geopolymer chemistry and properties. 1st International Conference on Geopolymer, 1, 25-48. Compiegne.

Davidovits, J. (1991). Geopolymers: Inorganic polymeric new materials. Journal of Thermal Analysis and Calorimetry, 37, 1633-1656. doi: https://doi.org/10.1007/BF01912193

Davidovits, J. (1994). Geopolymers: Man-made rock geosynthesis and the resulting development of very early high strength cement. Journal of Materials Education, 16, 91-139.

Davidovits, J. (2020). Geopolymer chemistry and applications. France: Institut Géopolymère.

Dimas, D. D., Giannopoulou, I. P., \& Panias , D. (2009). Utilization of alumina red mud for synthesis of inorganic polymeric materials. Mineral Processing and Extractive Metallurgy Review, 30, 211-239. doi:https://doi.org/10.1080/08827500802498199

Duxson, P., Fernández-Jiménez, A., Provis, J. L., Lukey, G. C., Palomo, A., \& van Deventer, J. S. (2007). Geopolymer technology: The current state of the art. Journal of Materials Science, 42, 2917-2933. doi: https://doi.org/10.1007/s10853-006-0637-z

Hajimohammadi, A., Provis, J. L., \& van Deventer, J. S. (2008). One-part geopolymer mixes from geothermal silica and sodium aluminate. Industrial \& Engineering Chemistry Research, 47, 93969405.doi:https://doi.org/10.1021/ie8006825

Jithendra, C., \& Elavenil, S. (2020). Effects of silica fume on workability and compressive strength properties of aluminosilicate based flowable geopolymer mortar under ambient curing. Silicon, 12(8), 19651974. doi: https://doi.org/10.1007/s12633-01900308-0

Koloušek, D., Urbanova, M., Andertova, J., Hulinsky, V., \& Vorel, J. (2007). Preparation, structure and hydrothermal stability of alternative (sodium silicate-free) geopolymers. Journal of Materials Science, 42, 9267-9275. doi: https://doi.org/ 10.1007/s10853-007-1910-5

Komnitsas, K., \& Zaharaki, D. (2007). Geopolymerisation: A review and prospects for the minerals industry. Minerals Engineering, 20(14), 1261-1277. doi: https://doi.org/10.1016/ j.mineng.2007.07.011

Konan, K. L., Peyratout, C., Smith, A., Bonnet, J.-P., Rossignol, S., \& Oyetola, S. (2009). Comparison of surface properties between kaolin and metakaolin in concentrated lime solutions. Journal of Colloid and Interface Science, 339(1), 103-109. doi: https://doi.org/10.1016/j.jcis.2009.07.019
Lecomte, I., Liégeois, M., Rulmont, A., Cloots, R., \& Maseri, F. (2003). Synthesis and characterization of new inorganic polymeric composites based on kaolin or white clay and on ground-granulated blast furnace slag. Journal of Materials Research, 18(11), 2571-2579. doi: https://doi.org/10.1557/ IMR.2003.0360

Lizcano, M., Kim, H. S., Basu, S., \& Radovic, M. (2012). Mechanical properties of sodium and potassium activated metakaolin-based geopolymers. Journal of Materials Science, 47(6), 2607-2616. doi: https://doi.org/10.1007/s10853-011-6085-4

Ma, C., Long, G., Shi, Y., \& Xie, Y. (2018). Preparation of cleaner one-part geopolymer by investigating different types of commercial sodium metasilicate in China. Journal of Cleaner Production, 201, 636647. doi: https://doi.org/10.1016/ j.jclepro.2018.08.060

Milkey, R. G. (1960). Infrared spectra of some tectosilicates. American Mineralogist: Journal of Earth and Planetary Materials, 45(9-10), 990-1007.

Palomo, A., Grutzeck, M. W., \& Blanco-Varela, M. T. (1999). Alkali-activated fly ashes - a cement for the future. Cement and Concrete Research, 29(8), 13231329. doi: https://doi.org/10.1016/S00088846(98)00243-9

Peng, M. X., Wang, Z. H., Shen, S. H., \& Xiao, Q. G. (2015). Synthesis, characterization and mechanisms of onepart geopolymeric cement by calcining low-quality kaolin with alkali. Materials and Structures, 48, 699708. doi: https://doi.org/10.1617/s11527-014-0350-3

Peys, A., Rahier, H., \& Pontikes, Y. (2016). Potassiumrich biomass ashes as activators in metakaolinbased inorganic polymers. Applied Clay Science, 119, 401-409. doi: https://doi.org/10.1016/ j.clay.2015.11.003

Poon, C.-S., Lam, L., Kou, S., Wong, Y.-L., \& Wong, R. (2001). Rate of pozzolanic reaction of metakaolin in high-performance cement pastes. Cement and Concrete Research, 31, 1301-1306. doi: https://doi.org/10.1016/S0008-8846(01)00581-6

Provis, J. L. (2009). Activating solution chemistry for geopolymers. In J. L. Provis, \& J. S. van Deventer, Geopolymers : Structure, processing, properties and industrial applications, 50-71. Cambridge: Woodhead Publishing. doi: https://doi.org/ 10.1533/9781845696382.1.50

Provis, J. L. (2014). Geopolymers and other alkali activated materials: Why, how, and what? Materials and Structures, 47, 11-25. doi: https://doi.org/10.1617/s11527-013-0211-5 
Provis, J. L., \& van Deventer, J. S. (2009). Introduction to geopolymers. In J. L. Provis, \& J. J. van Deventer, Geopolymers : Structure, processing, properties and industrial applications, 1-11. Cambridge: Woodhead Publishing. doi: https://doi.org/10.1533/ 9781845696382.1

Provis, J. L., Duxson, P., Kavalerova, E., Krivenko, P. V., Pan, Z., Puertas, F., \& van Deventer, J. S. (2014). Historical aspects and overview. In J. L. Provis, \& J. S. van Deventer (Eds.), Alkali Activated Materials, 13, 11-57. Dordrecht: Springer. doi: https://doi.org/10.1007/978-94-007-7672-2_2

Provis, J. L., Lukey, G. C., \& van Deventer, J. S. (2005). Do Geopolymers actually contain nanocrystalline zeolites? A reexamination of existing results. Chemistry of Materials, 17(12), 3075-3085. doi: https://doi.org/10.1021/cm050230i

Sathonsaowaphak, A., Chindaprasirt, P., \& Pimraksa, K. (2009). Workability and strength of lignite bottom ash geopolymer mortar. Journal of Hazardous Materials, 168(1), 44-50. doi: https://doi.org/10.1016/j.jhazmat.2009.01.120

Shi, C., Fernández-Jiménez, A., \& Palomo, A. (2011). New cements for the 21st century: The pursuit of an alternative to portland cement. Cement and Concrete Research, 41(7), 750-763. doi: https://doi.org/10.1016/j.cemconres.2011.03.016

Shvarzman, A., Kovler, K., Grader, G., \& Shter, G. (2003). The effect of dehydroxylation/amorphization degree on pozzolanic activity of kaolinite. Cement and Concrete Research, 33(3), 405-416. doi: https://doi.org/10.1016/S0008-8846(02)00975-4

Sturm, P., Greiser, S., Gluth, G. J., Jäger, C., \& Brouwers, H. (2015). Degree of reaction and phase content of silica-based one-part geopolymers investigated using chemical and NMR spectroscopic methods. Journal of Materials Science, 50, 6768-6778. doi:https://doi.org/10.1007/s10853-015-9232-5

Tonak, T., Sipahi, F., \& Atay, Y. (1997). Elektrometalurji Sanayii Atık Ürünü Silis Dumanı'nın Çimento Üretiminde Kullanılması. Endüstriyel Atıkların Inşaat Sektöründe Kullanılması Sempozyumu, 169183. Ankara: TMMOB İnşaat Mühendisleri Odası.

van Jaarsveld, J. G., van Deventer, J. S., \& Lukey, G. C. (2002). The effect of composition and temperature on the properties of fly ash- and kaolinite-based geopolymers. Chemical Engineering Journal, 89(1-3), 63-73. doi: https://doi.org/10.1016/S13858947(02)00025-6

Ye, N., Yang, J., Liang, S., Hu, Y., Hu, J., Xiao, B., \& Huang, Q. (2016). Synthesis and strength optimization of one-part geopolymer based on red mud. Construction and Building Materials, 111, 317-325. doi: https://doi.org/10.1016/j.conbuildmat. 2016.02.099

Yeğinobalı, A. (2009). Silis dumanı ve çimento ile betonda kullanımı. Türkiye Çimento Müstahsilleri Birliği, 27-36. 